\title{
Black Gold, White Power: Mapping Oil, Real Estate, and Racial Segregation in the Los Angeles Basin, 1900-1939
}

\author{
DANIEL G. CUMMING \\ NEW YORK UNIVERSITY
}

\begin{abstract}
In 1923, Southern California produced over twenty percent of the world's oil. At the epicenter of an oil boom from 1892 to the 1930s, Los Angeles grew into the nation's fifth largest city. By the end of the rush, it had also become one of the most racially segregated cities in the country. Historians have overlooked the relationship between industrialists drilling for oil and real estate developers codifying a racist housing market, namely through "redlining" maps and mortgage lending. While redlining is typically understood as a problem of horizontal territory, this paper argues that the mapping of the underground-the location and volume of subterranean oil fields, in particular-was a crucial technique in underwriting urban apartheid. Mapping technologies linked oil exploitation with restrictive property rights, constructing oil as a resource and vertically engineering a racialized housing market. By focusing on petro-industrialization interlocked with segregationist housing, this article reveals an unexamined chapter in Los Angeles's history of resource exploitation and racial capitalism. Moreover, it contributes to a growing literature on the social production of resources, extractive technology and political exclusion, and the technoscientific practices used by states and corporations to mine the underground while constructing metropolitan inequality above ground.
\end{abstract}

\section{Keywords}

oil; resources; technology; real estate; segregation; race; redlining; urban; suburban

\section{Introduction}

In 1927, Upton Sinclair, renowned author of The Jungle, published his latest indictment of exploitative industry in America. His novel, Oil!, fictionalized the Los Angeles oil boom of the 1920s, focusing particularly on Signal Hill near Long Beach. Sinclair knew Signal Hill well. His wife, Mary Craig Sinclair, owned property near an oil well that had erupted in a 114-foot geyser in 1921. Following the discovery, the Sinclairs drove from their Pasadena home to meet with neighbors who were debating leasing their residential lots to drilling companies. In heated community meetings, Upton witnessed "human nature laid bare! Competition in excelsis. The

'Daniel G. Cumming, Email: daniel.cumming@nyu.edu

Copyright (c) 2018 (Daniel G. Cumming). Licensed under the Creative Commons Attribution Non-commercial No Derivatives (by-nc-nd). Available at estsjournal.org. 
whole industry-free, gratis, for nothing!" Mary described neighbors "suddenly seized with the vision of becoming 'big people' driven half-crazy with a mixture of greed and fear." Upton began writing immediately. When Mary asked what the book would be about, he replied, "The whole of Southern California, the new land of black gold" (Tygiel 1997).

Beginning in the 1890s, oil discoveries across the Los Angeles Basin boomed, generating new industrial-residential suburbs in their wake (Viehe 1981). With each discovery, workingclass families from the east migrated to Los Angeles's growing petro-suburbs to work in the oil industry (Quam-Wickham 2001; Sabin 2005; Elkind 2011). As one of the most prolific oil regions in the world by 1923, the basin produced twenty percent of the global output (Schmitt, Dugan, and Adamson 2003). Observers described, awe struck, the "forests of oil derricks" that sprouted across the metropolitan landscape (Workers of the Writers' Program 1941).2

By the 1930s, however, many Angelenos discovered their oil-rich properties degraded, even blighted, in real estate appraisals. In the depths of the Great Depression, the federal government created new housing agencies and lending policies to resuscitate a crashing housing market: the Home Owners Loan Corporation (HOLC) and the Federal Housing Administration (FHA). Working in concert, federal agents and local realtors established new standards for distributing New Deal mortgage securities. A key tool in this endeavor were Residential Security Maps, known notoriously as "redlining maps." Appraisers color-coded entire neighborhoods according to their credit risk, rewriting the terms under which residents could secure a home loan. As many historians have detailed, redlining institutionalized segregationist policy in which lenders channeled credit toward white neighborhoods backed by racially restrictive covenants (Jackson 1985; Sugrue 1996; Hirsch 2000; Freund 2007). In Signal Hill, the world's richest oil deposit in barrels per acre, residents watched as appraisers redlined their entire community. ${ }^{3} \mathrm{By}$ way of explanation, appraisers noted the "subversive influence of the Signal Hill oil field." They also reported, more damningly, an "increase of subversive racial elements" (D63 HOLC 1939).

Such "subversive" threats deserve a closer look: while one was a material resource, fixed under geologic layers and extracted through sophisticated technology, scientific knowledge, and property rights; the other was both imagined and embodied, a social fear conjured through historical and political economic structures, one that locked "Mexican, Japanese, and Negro residents" into predatory property regimes (D63 HOLC 1939). As a global leader in oil production and one of the nation's most racially segregated cities by 1940, Los Angeles begs the question: what was the relationship between hydrocarbon extraction and a racially segregated

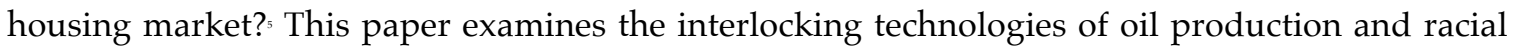
segregation created by industrialists, geologists, real estate agents, and federal appraisers. I argue

2Hereafter, Workers of the Writers' Program of the Work Project Administration will be referred to as WWP. ${ }^{3}$ By 1950 Signal Hill had produced 750 million barrels of oil (Schmitt et al. 2003).

* Hereafter, all in-text citations referring to redlining will identify the alpha-numerical report for each property appraised by the HOLC in 1939. For example, Signal Hill was appraised as D63 by HOLC in 1939 (D63 HOLC 1939). All property reports can be found in the online database "Mapping Inequality" (Nelson et al. 2016).

${ }^{5}$ Los Angeles had a segregation rate of .821 in 1940, according to sociologists. In comparison, Chicago was .893 , and New York was .798 (Cowgill and Cowgill 1951). 
that mining, speculating, and mapping subsurface resources was crucial to the engineering of residential apartheid in metropolitan Los Angeles. By focusing on an era in which the petroleum industry reached its high-water mark, one that overlapped with the institutionalization of segregationist housing policies, this paper reveals an unexamined chapter in Los Angeles's history of resource exploitation and racial capitalism.

Between the 1890s and 1930s, Los Angeles's oil fields underwent a significant shift in value through technological mediations of resource and real estate. As extraction became less speculative, industrialists honed their geological knowledge through survey maps and drilling innovations. A migrant workforce, largely white and recruited by the petroleum industry, convinced real estate developers of the need to fine-tune the legal instruments underwriting homeownership. Through the 1920s, developers utilized maps in particular to detail resource extraction in relation to growing neighborhoods, and with property deeds that mandated white homogeneity, helped align subterranean values with above-ground housing investments. The crisis of the Great Depression, however, ushered in a new system for granting home loans. On an unprecedented scale, the federal government financially backed a housing market that overbuilt the suburbs and under-developed the city. Banks and lenders relied on the knowledge of federal appraisers, who utilized legal technologies, including deeds, contracts, and restrictive covenants, to inform their analysis. Preserving whiteness emerged as a dominant concern for investors. The oilfields were no exception. Influenced by theories on the asset value of race and property, local realtors and federal agents appraised both oil fields and housing markets through the same lending maps. Petroleum workers and their families who failed to insure the racial character of their neighborhoods suffered redlining, and with it went the privileges of securing valuable home mortgages. As property values declined, many residents sought home loans elsewhere.

Redlining, in effect, fixed the burdens of petro-industries in neighborhoods across South Los Angeles, rending the industry noxious and resident communities toxic for future investment. Following WWII, African Americans and Mexicans migrated in unprecedented numbers to metropolitan Los Angeles only to be denied home loans everywhere but the city's redlined neighborhoods. Decades of civil rights activism helped knock down barriers to fair housing, but pathways out of the city often led residents to its redlined petro-suburbs. Black and brown communities found themselves locked in toxic neighborhoods intimate to noxious industry, environments of "slow violence" that undermined residents' wealth and health for generations (Nixon 2011). Historical extractions of black gold, therefore, conditioned the postwar "investment in whiteness," establishing an ecological foundation to a residential landscape made separate and unequal (Lipsitz 1998).

' For apartheid in the US housing market, see Massey and Denton (1993). The literature on racial capitalism is vast, but Cedric J. Robinson provides the foundational account of race and capital as intertwined processes in Black Marxism (1983). Robinson argues that racialism and capitalism emerged together within Europe's feudal order, and capitalism's expansion through slavery, imperialism, and colonialism relied on the elaboration and exploitation of racial differences. This paper explores racial capitalism in the twentieth century through the emergence of a racialized housing market driven by private capital and state policy.

"For "investment in whiteness," see Lipsitz (1998); for framing of segregated Los Angeles through the lens of "white privilege," see Pulido (2000). According to Census data between 1940 and 1970, the African 
This paper engages three significant themes in the field of Science, Technology, and Society: the social production of oil as a resource, extractive technology as a method of political exclusion, and the technoscientific practices utilized by states and corporations to mine the underground while constructing metropolitan inequality on the surface. Together the themes argue for conceptualizing knowledge, expertise, and power as a deeply entangled history, one that cannot be divorced from its material landscape.

First, rather than carrying inherent social value, oil became a resource through specific historical conditions. As an alternative to coal in the late-nineteenth century, engineers discovered crude oil to be a useful fuel for new transportation technology. The automobile and its combustible engine, in particular, remade the spatial dimensions of the modern metropolis. Instead of rigidly maintaining a conceptual binary between states of nature and society, scholars have recently argued that natural resources produce both "society" and "nature" simultaneously, a point that emphasizes hybrid connections between human and non-human environments (Bakker and Bridge 2006). ${ }^{\circ}$ Oil made Los Angeles as much as Los Angeles made oil. Furthermore, industrialists extracted oil through speculative and evolving technologies. Uncertainty drove the process in making oil a resource. Counter to any assumptions of linear progress, geologists, engineers, and industrialists haphazardly developed their knowledge base, and thus the material landscape, by relying on experimental equipment, exploratory sites of production, businessfriendly policies, and transregional networks of expertise and labor. Embodying what Thomas Hughes calls an "ecotechnological system," surface-level industries capitalized subterranean hydrocarbons through networked terrains of knowledge and technology, which together, translated materials into resources and human society into a profitable venture (Hughes 2004).

Second, technologies that mapped the underground, and thus created oil as a resource, became a crucial technique in engineering racial segregation above ground. The underground, a spatial context that political geographers describe as a "third dimension," offers volume and verticalilty as dimensions of human experience that stretch horizontal, and thus area-bound, conceptions of territory (Braun 2000; Bridge 2013). Due to the horizontal limits of US property rights, the petroleum industry negotiated vertical claims on the underground through legal technologies that underwrote above-ground access to below-ground resources, including maps, contracts, leases, deeds, and land use policies. By defining multidimensional terms of territory through technologies that codified exclusive access, the city's white authorities ensured that resource-rich lands remained securely within the accumulative logics of white supremacy. Leo Marx highlights political exclusion as a constitutive feature in the concept of "technology," one

American population in Los Angeles County increased 905 percent: 75,206 to 755,719. The Hispanic population increased 2,004 percent: 61,248 to $1,288,716$. The white population increased 83 percent: $2,620,450$ to $4,798,872$ (Ethington et al. 2001).

"Scholars have previously conceptualized the nature-society binary through a lens of historical materialism, or first and second natures. Building on the work of Karen Bakker and Gavin Bridge, this paper instead emphasizes simultaneity or "hybridity" over a distinctive binary. For other examples, see Ferry and Limbert (2008), Bridge (2009), and Richardson and Weszkalnys (2014).

. On this process, more broadly in oil production, see Appel (2012), Weszkalnys (2014), and Weszkalnys (2015). 
that smuggles racialized assumptions of civilization and progress into uncritical notions of modernity (Marx 2010). In Los Angeles, a city built on settler colonialism, municipal authorities and regional corporations utilized industrial and real estate technology to order an extractive industrial base, managing control over vertical networks that harvested, even colonized, the underground in the interest of modern development. The same technologies ensured that nonwhite residents would be concentrated in vulnerable spaces, often sites of waste and pollution. Revealing the effects of decidedly non-neutral technology, Los Angeles's colonization of the underground would tax black and Latino residents' properties, wealth, and health for generations.

Third, the relationship between metropolitan inequality and knowledge of the underground reveals the role of state and corporate power in reshaping the material landscape. As scholars of technology have argued, corporate investments in producing natural resources recreate a material world informed by intersecting hierarchies of race, class, and gender as well as the qualities of the material itself (Lerman 2010; Rolston 2013). Historians, in turn, have demonstrated how industrial exploitation of rural hinterlands played a significant role in creating uneven urban growth (Cronon 1991; Klingle 2007; Needham 2014). However, the emerging literature on metropolitan development, in particular its suburban spaces, has yet to attend to the underground (Kruse and Sugrue 2006). The geographic concentration of oil in Los Angeles's petro-suburbs presents a valuable case in contrast. Moreover, land ownership and property rents help clarify the spatial relationship between underground resources and racial and class segregation. With the benefits of a fossil-fueled society fixed on a largely white middle-class periphery, industrial landowners across South Los Angeles's working-class suburbs collected rents and royalties from oil companies, while the heavy costs of production compounded among residents confined to its redlined spaces. The co-production of oil as a resource and a geography of exclusion illustrate interlocking technologies at work in engineering decades of racial inequality. As this paper demonstrates, oil and its attendant geography were anything but natural, and for Angelenos living above the black gold, proximity hardly equaled power.

I build this argument in three parts. The first section of the paper documents the discovery of oil in Los Angeles and the formation of its petro-suburbs. Section two examines settlement patterns during oil's boom period in the 1920s. Section three identifies the early 1930s as a key moment in resource extraction and real estate development. The final section explores how environmental inequality was engineered through policies informed by federal housing maps in the 1930s and beyond.

\section{“Million-dollar Views Became Million-dollar Leases" 1900-1920}

In the Los Angeles Basin, oil comes from lower Pliocene and upper Miocene strata, a 5-millionyear history pressurized more than 1,600 feet below the surface. ${ }^{10}$ Settling along fault lines, such as

10 By 1961, the Los Angeles Basin had produced over 5 billion barrels of oil, accounting for nearly half of California's total output (R.F. Yerkes et al. 1965). 
the Newport-Inglewood Fault, hydrocarbons pooled in sediment layers and migrated into stratigraphic traps. Oil formed under Westside Los Angeles and Beverly Hills. It blotted the basin from Inglewood to Signal Hill, amassed in hinterlands near Whittier and Santa Fe Springs, and spread along the coast to Huntington Beach. While drilling began sporadically in the 1880s, the region's oil boom originated in a west Los Angeles town lot where Edward Doheny struck oil in 1892. In the decades that followed, oil production engulfed the region.

The discoveries turned Los Angeles into a sprawling industrial metropolis, defying typical urban growth that followed transportation lines (Viehe 1981). Concentrations of industry and residence followed each erupting geyser, stamping the region with clusters of fossil fuel infrastructure. In urban lots, suburban yards, beach fronts, farm towns, and foothills, the drilling bonanza ultimately produced a regional network of petro-suburbs linked through roads, refineries, pipelines, and tank farms. The city's future appeared hitched to its ancient deposits. "Almost overnight," according to one writer, "'million dollar views' became million dollar leases" (WWP 1941).

To match the region's unique geography, California operators adapted cable drilling technology from Pennsylvania. Operators incorporated a rotary drilling rig from the Gulf Coast, featuring a motor-driven pump with mud circulation to clean the hole as it drilled. They built massive derricks to hold the weight of the drill pipe, and they added stronger bits and casing than previously used. With wooden braces crosshatched vertically, the derricks towered over 100 feet tall, straddling a platform of gears, wheels, and cranks that plunged the steel-toothed drill through a hole encased with cement. A roaring engine was lubricated with tanks of fuel and water, and a mud pit disposed of the debris that spewed from the hole. Operators drilled to depths never before reached, averaging 2,000 feet between 1900 and 1919. Once oil was struck, they removed the drill and installed a pump to regulate flow for the market (Schmitt, Dugan, and Adamson 2003)." Drilling typically drew a crowd. Signal Hill, like "an aroused porcupine," according to observers, "bristles with derricks." Residents marveled at the nighttime lights, which turned Signal Hill "into a curious, gaunt, illuminated forest" (WWP 1941).

As a commodity, oil only materialized for those who could secure property above the deposits. Surface and subsurface rights, therefore, were in tension, even alienated from one another as "split estates" (Bridge 2013). Courts abided by the "rule of capture," a nineteenthcentury precedent that stipulated landowners had a right to material below ground, but minerals could not be claimed until drawn to the surface (Sabin 2005). A writer from the period described the problem: "An oil pool is a geologic and economic unit, but is not developed as such. Legally, every producer owns all the oil under his property, but oil is no respecter of property lines and flows toward the nearest well" (WWP 1941). Subsequently, the placement of oil derricks determined profits, and improvised methods of extraction, such as slant drilling, characterized the frenzy of speculation (Schmitt, Dugan, and Adamson 2003)."

"By the 1950s the deepest wells would reach almost 15,000 feet.

${ }_{12}$ Operators often drilled multiple wells to ensure competitors could not "steal" oil. By the 1930s, slant drilling technology allowed operators to mine horizontally, eliminating the need for extra wells. By the 1940s, companies increasingly contracted with specialized firms, which kept costs low and introduced new 
As a legal principle codified in the spirit of the free market, the rule of capture hardly lived up to its implications of equal opportunity. Regulated property markets determined who could access the riches below, and oil operators allied with real estate speculators to plan the political geography of the petroleum economy. In a matter of decades, oil companies accumulated vast holdings of land, and as major real estate institution, they constricted space for homeowners trying to gain a foothold in the region.

Oil, however, remained unbound by real estate. Discoveries under commercial, residential, and public properties meant that companies often leased resource rights from individual property owners. Leases typically specified a period of time for drilling, and operators paid royalties per acre along with land rent. The standard royalty was one-eighth of the production percentage, although some landowners charged more. Signal Hill landowners reportedly charged royalties at one-half the production. Furthermore, many leases stipulated that operators drill multiple wells to mitigate the threat of rival producers; thus, operators had an incentive to acquire acres of land to manage the development of a particular field (Schmitt, Dugan, and Adamson 2003). Land ownership and oil rents, therefore, underwrote metropolitan development as the industry's tentacles unfurled throughout the basin.

By 1910 railroads had switched to burning oil over coal (Woehlke 1910). Precise knowledge about the location of oil deposits became increasingly valuable. In 1906 petroleum engineer Ralph Arnold plotted a "street and section" view of the Los Angeles City oil field. Featuring a smattering of black dots, and with thumbprints smearing the margins, the map pinpointed all "oil wells producing or drilling." Wells clustered at the far west side of the city, near La Brea and Fourth Street; bordered Vermont Avenue, Third Street, and Hoover Street; and stretched across the northern city center in a thick artery, from Hoover Street to the Los Angeles River. Arnold's careful noting of anticlines, sands, and faults suggests this three-to-four-mile stretch was put to good use.

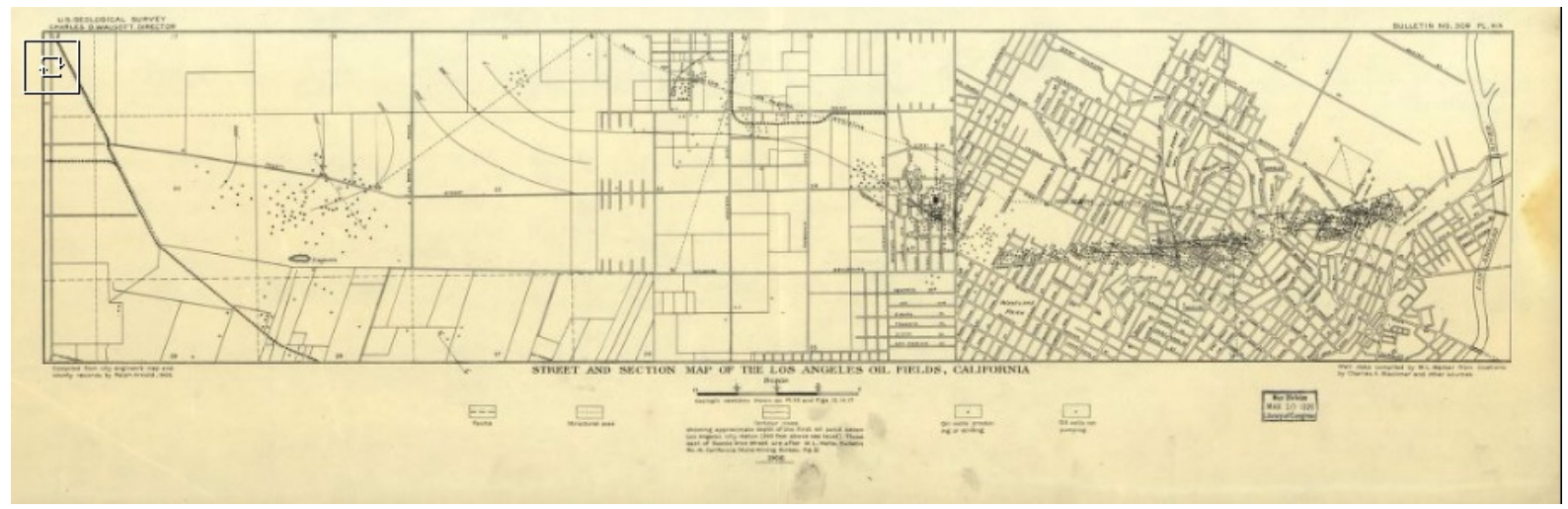

Figure 1. "Street and Section Map of the Los Angeles Oil Fields" (A. Hoen \& Co. 1906).

technologies, such as seismic surveys and experimental recovery methods. Secondary recovery methods, including water flooding, steam cycling, and gas injection, were not widespread until the 1960s (Schmitt et al. 2003). 
Geologists and engineers like Arnold created a new knowledge base about the region's resource capacities. Mapping an underground only visible through trained observations of topology, geologists choreographed oil speculation by plotting deposits and predicting the untapped volume. Prior to this scientific turn, an earlier generation of drillers had relied on gut feelings, sixth senses, and con men who exploited the gullible. ${ }^{3}$ When operators struck oil unexpectedly, geologists rewrote their maps to incorporate an expanding view of the underground. Together, these efforts helped transform a social and ecological landscape. By pinpointing potential resources thousands of feet below the surface, geologists opened the underground to vertical speculation by capitalists of oil and land.

As the region's oil supply grew, manufacturers incorporated petroleum compounds into hundreds of new products, and by 1949 the consumption of oil and gas exceeded all other energy sources (Schmitt, Dugan, and Adamson 2003). Between 1900 and 1920, oil prices leapt from a low of 62 cents per barrel to a high of 3.07 dollars per barrel, and when the U.S. military became a leading oil consumer, a new relationship was charted between fossil fuels and the warfare state (US EIA n.d.). In turn, Los Angeles grew in size and power by annexing many of its resource-rich suburbs. Signal Hill, however, incorporated into its own city in 1923. Foreshadowing local contestations that would intensify in the coming decades, Signal Hill effectively locked in place its property taxes and resisted external attempts to absorb its oil operations.

\section{"Life is Better in California" 1920-1929}

In 1923, Sunset Magazine, a travelogue of the Southern Pacific Railroad, published a map advertising California. Mixing bold type with cursive flourish, its appeal was dramatic: "California, build Your Tomorrow Here." The logic was straightforward: "There are today in California some 3,500,000 people scattered sparsely over a territory that is amply capable of supporting a population of $50,000,000$...The moral is obvious...Life is Better in California." Layered on the topography, icons identified the region's most important assets. The state's only industries, in fact the only assets representing Los Angeles aside from an observatory, were its oil fields. Yet the advertisement appealed directly to families, describing how "homes are more homelike, schools are bigger and teachers are better paid." Evidently, boosters' call to "build Your Tomorrow Here" envisioned a future for families intimate to the oil industry (Californians, Inc. 1923).

${ }^{13}$ W.E. Youle describes the "expertise" many con artists claimed to possess: "The magic box with an electric bell would strike when the boundaries of a field were entered...the bell would then toll the number of feet and the capacity of the well, if drilled. This contrivance was used all along the coast...it was all a farce, of course. They had an accomplice who kept them posted" (Youle 1926). 


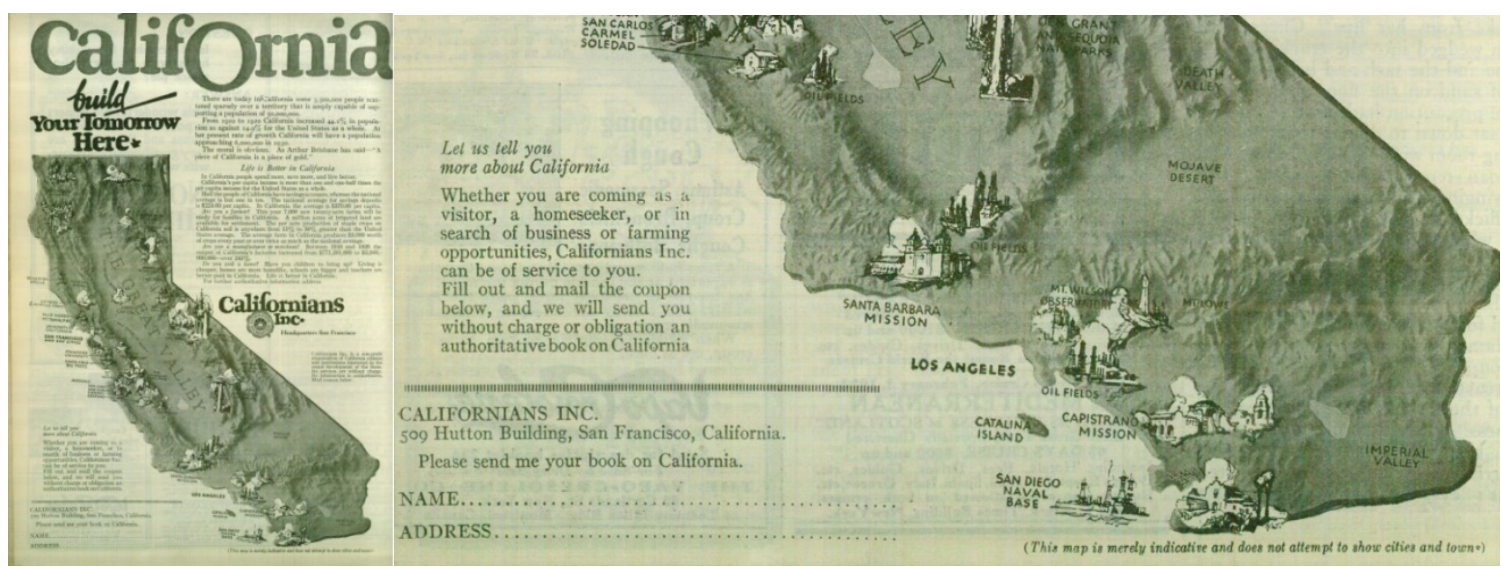

Figure 2. Sunset Magazine (Californians, Inc. 1923).

Between 1920 and 1930, Los Angeles's population grew from 576,673 to 1,238,048, making the city the fifth largest in the U.S. The county population increased even more dramatically, over 135 percent, topping off at 2,208,492." Oil corporations, most notably Standard Oil of California, Union Oil Co., and Shell Oil Co., dominated the region economically, while urban elites, led by the City Council, the City Planning Commission, and the Realty Board, aligned their efforts to promote an open-shop, anti-union business climate (Davis 1997; Hise 2001). Boosters championed the city as the nation's "white spot," an appeal to its agricultural potential, but also a thinly veiled metaphor expressing fevered dreams for a racial utopia (Deverell 2005).

In 1921 the City Council approved its first comprehensive zoning plan. Adapting a 1904 land use ordinance, the first in the nation, the comprehensive plan benefited commercial properties at the expense of all others, a near "hegemony of speculative real estate interests," according to one historian (Whittemore 2012). The federal government, in turn, eyed warily the region's consolidation of power over its fossil fuels. Shifting from a previous policy encouraging unregulated mining, the federal government passed the 1921 Mineral Act in an attempt to establish a framework for resource conservation. The act lacked full regulatory teeth, however, committed as it was to conserving resources only on public lands. ${ }^{16} \mathrm{~A}$ follow-up state and federal compromise in 1929 attempted again to regulate oil production, but its voluntary incentives

${ }^{14}$ Los Angeles County: 936,455 to 2,208,492. Los Angeles City: 576,673 to 1,238,048, a 114 percent increase (California State Data Center).

${ }_{15}$ The "white spot" metaphor was often used to compare Los Angeles as racially favorable to San Francisco, Chicago, New York, and other major industrial cities (Deverell 2005).

${ }_{16}$ The Teapot Dome scandal in 1921-22, which exposed Doheny's Pan-American Petroleum Company in a secretive agreement with the Secretary of the Interior, made clear that oil companies' reach extended all the way to the executive office (Sabin 2005). 
carried little effect (Sabin 2005)." Consequently, oil corporations and real estate interests reigned supreme throughout the decade.

Laborers migrated from across the country to work in the basin's lucrative oil industry. White supremacy in the "white spot," however, structured labor relations in the growing industry. According to a 1931 study, oil production was one of the most racially segregated industries in the region. In a survey of five sites, 1,214 workers total, only one worker was African American. Likewise, employers were determined to "not employ [negroes] in the future" (Ervin 1931). The Los Angeles Times described prevailing attitudes bluntly: "Any [new arrivals] that are not thus assimilable, California finds a way to shed and slough off. No state in the Union, for all its infinite variety, is so determined to be one-hundred-per-cent American as this great Pacific commonwealth" (Bowling 1920).

While locked out of the petroleum industry, African Americans were locked into predatory housing markets. A relatively small community prior to WWII, black Angelenos suffered daily threats of violence, and restrictive covenants ensured that property, and power, stayed in white communities (Flamming 2006). In South Central and Watts, African Americans lived in neighborhoods bordered by restrictive covenants, apartheid-like in design and effect (Massey and Denton 1993). Residents of Hawthorne, an oil town neighboring Watts, enforced whites-only "sundown town" rules. A sign posted at city limits, displayed well into the 1930s, made the threat clear: "Nigger, Don't Let The Sun Set On YOU In Hawthorne" (Loewen 2005).

A journalist for the Times, however, was surprised to find that "the Los Angeles Negro colony" was able to "thrive and expand...with a business and social structure all its own" (Gardner 1933). Defying white expectations, the "Negro colony" centered on Central Avenue grew into the West Coast's largest "Black Metropolis." Frequently drawing comparisons to Chicago's Bronzeville and New York's Harlem, Central Avenue's renowned cultural, political, and economic institutions supported a black community flourishing under the hegemony of white supremacy (Gregory 2006; Drake and Cayton 1945).

In East Los Angeles, particularly Boyle Heights and Belvedere, Mexican Americans also faced employment discrimination within the petroleum industry. Negotiating segregated labor and housing sectors, generations of Mexican Americans, among the region's original inhabitants, built a transnational community, largely concentrated east of the Los Angeles River and stretching the borderlands between the U.S. and Mexico (Sanchez 1993; Gutierrez 1995). In the midst of the Great Depression, however, local authorities forced hundreds of thousands of ethnic Mexicans, citizen or not, to repatriate to Mexico, expelling about one third of Los Angeles's Mexican American community." Comparatively, Japanese Americans, while smaller in population, suffered restricted citizenship rights under the Alien Land Laws of 1913 and 1920.

"The 1929 strategy included a conservation law to cut oil production, organize cooperative oil mining in the Kettleman Hills, and establish an agreement among industry leaders to roll back production rates. The state, however, capitulated to oil companies' interests with the State Lands Act of 1938, which allocated 30 percent of oil royalties to fund an expanding state park system (Sabin 2005).

is While exact numbers are difficult to calculate, historians estimate that 400,000 to 1 million residents from were forced to repatriate to Mexico from the U.S. 
During WWII, moreover, landlords evicted their Japanese tenants, some of whom farmed land that was later leased to oil companies. City leaders acting on "common sense," according to Mayor Fletcher Bowron, incarcerated 120,000 Japanese Americans in internment camps under Executive Order 9066 (Kurashige 2008).

White migrants from the Midwest and South benefited immensely from the exclusions of African American, Mexican American, and Japanese American residents. Recruited by oil companies, most migrants were working-class, and many leased their homes from oil companies in company towns. Merle Van Ness Hale, a resident of Olinda, an oil town bordering Los Angeles County, described it simply: "The oil people were very friendly and quite loyal to each other, and always helpful. They were migrants, and they went where the oil was" (Beko 1979).

Bringing a distinctively southern culture to California, the migrants created familiar small-town communities." In Olinda, nearly every man worked for the oil companies, while women and children worked in the home and in nearby packing houses. A blue-collar culture with domestic sites of production and shared dreams of homeownership characterized Los Angeles's early petro-suburbs (Quam-Wickam, 2001; Nicolaides 2002). The Great Depression, however, ushered in a period in which oil companies cut costs by terminating company-owned housing. Families were evicted from company leases. Resident Jessie Isbell recalled that some families remained as long as oil could be extracted. "When they fenced our yard, they just fenced out that oil well that was so close to our house. So, we had a little backyard and the well there, pumping all the time" (Beko 1979).

For California migrants, the depression threatened to erase their tenuous gains. In the first five years of the 1930s, oil prices dropped from the previous decade-long average of 1.83 dollars per barrel to a low of 65 cents (US EIA n.d.). The local effects of the depression were compounded by oil discoveries in East Texas and the rise of the Texas oil industry, which shifted the center of national production to the Midwest. Companies in the Los Angeles Basin continued to expand, however, setting up the 1930s as a pivotal decade for the fossil fuel industry and its relationship to metropolitan development.

\section{"More Oil Fields Will be Discovered" 1929-1930}

In 1929, Richfield Oil Company, one of the larger companies in the region with \$94 million in assets and 74,000 acres of land, commissioned an appraisal of its holdings, producing detailed maps of every oil well and acre it owned. In Signal Hill, its oil wells dotted residential, commercial, and public spaces, including stores, parks, and schools. ${ }^{20}$ With operations stretching from Long Beach to Huntington Beach, the company maintained a confident outlook for new

19 As Harold Van Patten described it, "there was a basic group of people who came from Drake's Creek, Arkansas...they had their own speech and ways of doing things" (Beko 1979).

${ }^{20}$ Between 1923 and 1929, the company expanded its wells from 20 to 560 and grew its land from 968 to 74,000 acres. As a result, its capital assets multiplied by 868 percent, from $\$ 9,759,985$ to $\$ 94,450,747$. Richfield ranked only the eighth largest oil company in the region, still a minor player compared to Standard Oil (Beal 1930). 
decade: "The company should, by all means, institute a broader geological policy with the view of increasing its proved oil reserves. There can be no doubt that more oil fields will be discovered in California" (Beal 1930).

The 1930s was a crucial period for the petroleum industry. As fossil fuel extractions expanded regionally, the industry remade the landscape by exploiting the underground. Hinting at the shifting currents, the Times boasted the region's industrial and agricultural output in 1930: "The Los Angeles County again leads every other county in the United States." Reporters celebrated "the mineral production of the subsoil, chiefly oil," which had produced over half the capital value of all other agriculture combined (Los Angeles Times 1930). Another article, however, registered a note of unease with the destruction of an old order to make way for the new: "At one time some of the best orange groves in Southern California were on land that now is the center of the Los Angeles residence and industrial district" (Los Angeles Times 1930).

As oil companies reached deeper for profits, the real estate industry consolidated its power above ground. Revising the real-estate friendly comprehensive zoning plan in 1930, the Los Angeles Planning Commission restricted oil production to at least one-half mile from residents of twenty or more. Consequently, real estate developers profited by flipping old oil properties declining in value. A Times reporter described the transition in La Brea, one of Los Angeles's earliest fields located south of Hollywood: “Within the last three years upward of 100 old derricks have been removed...the scattering few which remain will shortly be taken down to make way for real estate improvements" (Los Angeles Times 1930).

Capitalizing on a landscape in transition, the real estate industry shored up a legal framework that sheltered property value from external threats. In addition to protecting against industrial encroachment, developers codified exclusionary tactics that had long promoted white homeownership. As early as 1924, the National Association of Real Estate Boards had amended its code of ethics, requiring realtors to "never be instrumental in introducing into a neighborhood...any race or nationality" who would be "detrimental to property values" (Gotham 2002).

In 1930, the Real Estate Commissioner's office of California instituted new licensing protocols, following a rise in predatory selling among "oil land operators" (Los Angeles Times 1932). Unsuspecting buyers, often elderly, were being conned by "oil sharks" into purchasing subdivisions of worthless property at exorbitant rates. Predatory dealers bused prospective buyers to newly discovered oil fields where under big tents with complementary hot dogs, salesmen sold parcels of land with little actual oil (Wilson 1923). The rampant exploitation, and negative press it received, gave the real estate industry an opportunity to assert more control over their market. It also provided an opportunity to formalize rights of access. Agents licensed under the 1930 protocols were required to "Learn [the] proper method of drawing deeds which will restrict the 'use and occupancy' to people of the Caucasian race" (Los Angeles Times 1930).

Prior to the onset of the Great Depression, real estate developers had issued racial restrictions largely piecemeal, through powers decentralized at municipal, city, and county levels. The nation's economic crash, however, ushered in a new federal era of public-private partnerships. Desperate to revive a collapsing housing market, federal agents worked directly 
with local realtors to create a coherent system of federally backed mortgage securities. A new standardized knowledge of credit risk would reformulate the relationship between ancient oil deposits and modern property values. Over the ensuing decades, Los Angeles's real estate industry institutionalized a racist housing market backed by federal financing and shaped by its hydrocarbon base.

\section{Mapping "Hazards" and "Subversives" 1934-1939}

Over the 1930s, local and federal realtors, appraisers, and lenders restructured the mortgage lending market. The technologies used, including residential security maps, economic reports, lending manuals, and geologic surveys of Los Angeles, highlight the extent to which race, residence, and resource were engineered in relation to one another. The hybridity between underground resources and surface-level politics institutionalized a rigidly segregated nature for the postwar city.

In the depth of the depression, the Home Owners' Loan Act of 1933 created the HOLC to intervene in a crashing housing market. A year later, the National Housing Act of 1934 established the FHA to regulate and insure long-term mortgage lending. The HOLC employed hundreds of appraisers to work with local realtors in evaluating neighborhood risk, and the FHA backed lenders issuing low-risk mortgages according to the new standards. To receive federal insurance, banks and loan organizations rewrote their practices in alignment with federal policy. Developers in the home building sector followed suit, and rates of homeownership rebounded dramatically (Highsmith 2015).2

The New Deal interventions saved the housing market, and the HOLC phased out its emergency acquisitions by 1936. Shifting gears, the HOLC formalized its appraisal standards to aid in allocating federal loans. Between 1935 and 1940, the HOLC created 239 residential security maps across the country. Intended for agency use only, the maps color-coded neighborhoods from green, "best"; blue, "still desirable"; yellow, "definitely declining"; to red, "hazardous." While a range of structural variables were analyzed, appraisers unequivocally marked a neighborhood hazardous when confronted with African American residents. In Los Angeles, each Area Description sheet came printed with a separate section for "Negro," and a percentage indicating the degree of "infiltration." Mexicans and Japanese were also listed as "subversive racial influences." In a particularly revealing report, appraisers wrote that it was "impossible to differentiate of goats, rabbits, and dark skinned babies...Like the 'Army Mule' [the neighborhood] has no pride of ancestry nor hope of posterity. It is a typical semi tropical countryside slum" (D57 HOLC 1939). By identifying neighborhoods as creditworthy only when

${ }^{21}$ Prior to the 1930s, mortgages were typically limited to fifty percent of a property market's value, with a three-to-five year repayment schedule that often ended in a balloon payment. The FHA required loans to be 30-year, self-amortizing, with low down payments. This stabilized and increased the size of the market by making previously unavailable loans accessible to a large percentage of the population, many of whom were first-time homeowners. The FHA insured eleven million mortgages between 1934 and 1972, and homeownership rates increased nationwide from 44 to 63 percent (Highsmith 2015). 
property restrictions protected against racial subversion, the federal government financed homeownership that catered exclusively to white residents, reinforced suburban homogeneity, and confined black and brown residents to predatory markets. In effect, decades of segregationist lending underwrote the most dramatic racial distribution of wealth and opportunity in the twentieth century. ${ }^{2}$

The Los Angeles Residential Security Maps, created in 1939, illustrate a bleak landscape. Nearly the entire core of Los Angeles was redlined, as was the east side of the river. On the west side, Beverly Hills and Hollywood received grades of green and blue. A red swath bled south into the Central Avenue District. Redlining flowed toward the sea, marking Inglewood, Watts, Compton, Hawthorne, Gardena, Torrance, Wilmington, San Pedro, and Long Beach. The reds and yellows in Redondo Beach, Hermosa Beach, Manhattan Beach, and Venice Beach colored the coast a patchwork of low grades before finding more stable green and blue foothills near Santa Monica. Across the northern rim of the city, including North Hollywood, Glendale, and San Marino, green and blue appraisals shaded suburban subdivisions. In south Los Angeles, with bold lettering stamped sideways, appraisers wrote "OIL FIELDS," circling several large fields, including "Baldwin-Hills Producing Oil Field," the largest urban oil field in the country (HOLC 1939).2.

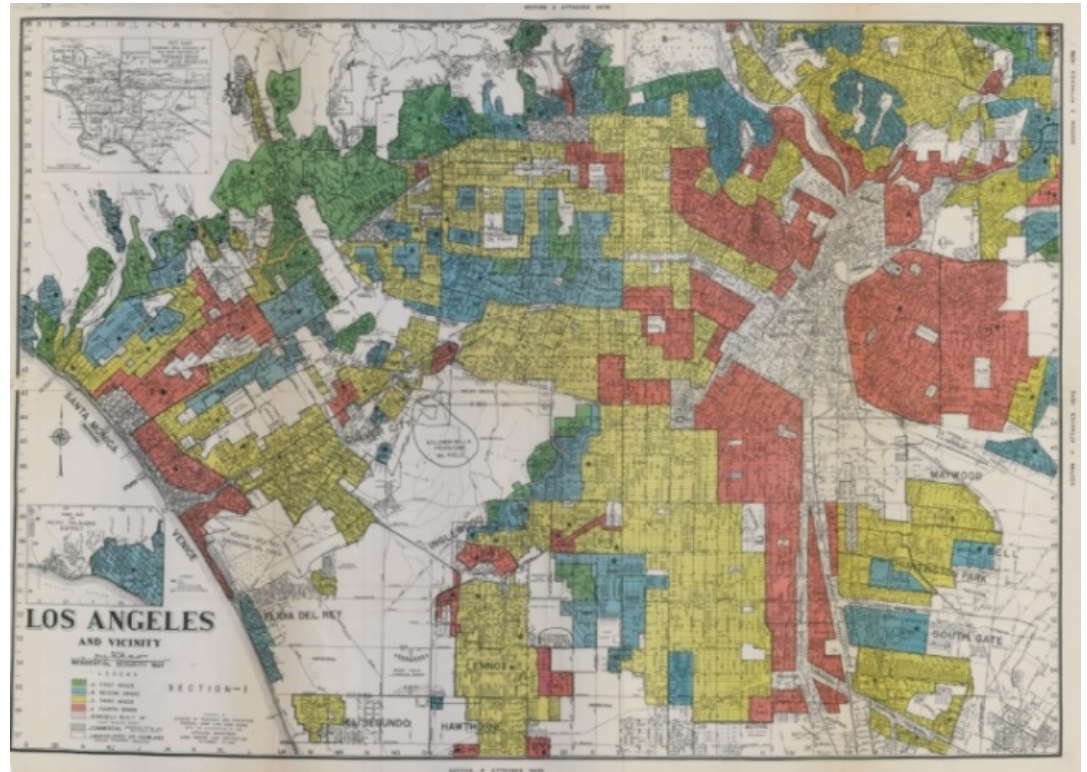

Figure 3. "Residential Security Maps," Section 1, Central Los Angeles, HOLC, 1939 (Nelson et al. 2016).

${ }_{22}^{2}$ For a perspective complicating the overall influence of redlining, see Greer (2013) and Hillier (2005).

${ }_{23}$ The survey was conducted by Theodore H. Bowden, Field Agent; Don W. Mayborn, Associate Economic Analyst, Division of Research and Statistics; and C.C. Boyd, Assistant Director in charge of city surveys. "Metropolitan Los Angles: Summary of an Economic, Real Estate, and Mortgage Finance Survey," Division of Research and Statistics, Federal Home Loan Bank Board, US. December 29, 1939 (Marciano et al.). 


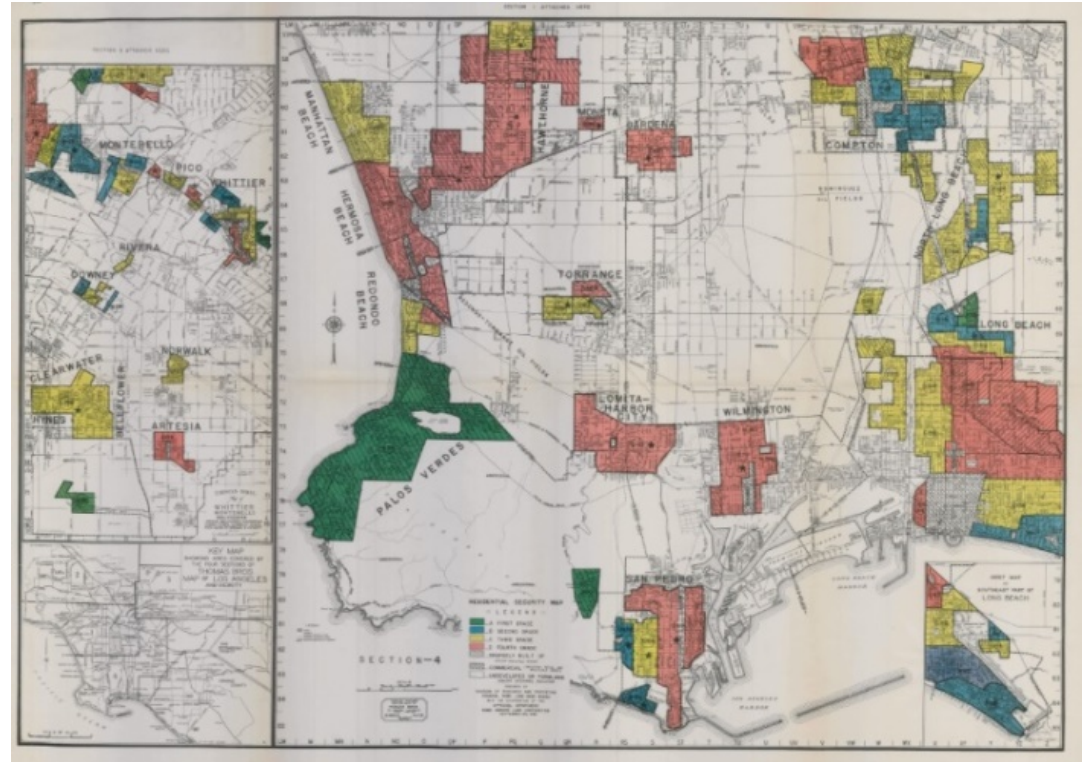

Figure 4. "Residential Security Maps," Section 4, South Los Angeles, HOLC, 1939 (Nelson et al. 2016).

Along with the Security Maps, the FHA Underwriting Manual provided a detailed guide for local and federal appraisers. Most importantly, as described in the Manual, "the presence of inharmonious racial or nationality groups" threatened secure investments (FHA 1936). Los Angeles in the 1930s, however, was overwhelmingly white. On the eve of the region's massive postwar migration, the 1940 Census counted only 75,206 African Americans, or 2.7 percent of the population; 61,248 Hispanics, or 2.2 percent; and 52,911 Asians, or 1.9 percent (Ethington 2001). Even so, HOLC appraisers relied on a racial hierarchy to evaluate property value. According to Homer Hoyt, Principal Housing Economist for the FHA, the negative effects of "a colored family" entering into a "white neighborhood" decreased as the family rose in income or "conform[ed] to American standards of living." Hoyt qualified his assessment, however, excluding "the case of Negroes and Mexicans" (Avila 2004).24 In addition to race, the Underwriting Manual outlined other factors for appraises to consider. Proximity to "adverse influences" was "one of the most important features" in assigning a grade. In this calculus, proximity to oil industries should have warranted an immediate downgrade. As stipulated by the manual, the location of "nuisances," a category that included loud and odorous industries, such as oil production, required appraisers to "severely penalize the location, perhaps to the point of rejection" (FHA 1936).

In reality, appraisers considered the oil industry to be a "nuisance" in highly contradictory ways. According to Area Description sheets, the region's oil industry affected 11.4

${ }^{2}$ As Hoyt viewed it, racial threats to property values could be ranked: "1. English, Germans, Scots, Irish, Scandinavians 2. North Italians 3. Bohemians or Czechoslovakians 4. Poles 5. Lithuanians 6. Greeks 7. Russian Jews of lower class 8. South Italians 9. Negroes 10. Mexicans" (Avila 2004). 
percent of neighborhoods surveyed. Appraisers noted oil production in 35 yellow- and redlined neighborhoods, and 13 green- and blue-lined neighborhoods. In redlined areas, oil production served as self-evident for a blighting grade. In redlined North Redondo Beach, for example, "proximity to oil wells precludes a higher grade." (D67 HOLC 1939).

In comparison, the oil industry in green- and blue-lined areas proved only slightly detrimental, and never blighting. Appraisers acknowledged the industry's negative effects, but consequences were always negotiable. More importantly, as long as the racial future of the neighborhood remained securely white, protected through racially restrictive covenants in the area's property deeds, oil properties were never penalized "to the point of rejection," as required by the Manual. In blue-lined North Long Beach, for example: "Parts of this area might be entitled to a 'low green' grade were it not for proximity to oil wells and refineries to the south" (B115 HOLC 1939). While in Alamitos Heights, "The area is assigned a provisional rating of 'low yellow,' but if oil well development is definitely abandoned it will be entitled to a higher grade" (C157 HOLC 1939). Surprisingly, in blue-lined Montebello, "proximity to oil fields is a favorable rather than detrimental influence" (B102 HOLC 1939).

A neighborhood's proximity to oil production clearly shaped appraisers' evaluations, but only when combined with "racial subversion" did the presence of oil actually produce a downgrade. In Area Descriptions that evaluated the oil industry and its nonwhite neighbors, appraisers utilized the rhetoric of contagion to warn of the "hazards" carried by both. Often these factors were listed in the same sentence, as if the two independent variables represented common, even interchangeable, levels of threat. In redlined Inglewood, for example, "adjacence [sic] to oil wells and industry, proximity to city dump and presence of inharmonious racial elements, renders an improved grade highly questionable" (D40 HOLC 1939).

Appraisers also relied on the knowledge of local informers to make their decisions. The description of blue-lined Whittier, for example, suggests that appraisers discussed the presence of oil with residents, deciding ultimately the threat could be managed: "Proximity to the Whittier oil fields is said not to be a detrimental influence" (B105 HOLC 1939). Appraisers in green-lined Oak Knolls, Long Beach, noted that the "Proximity to oil wells" was acceptable because a zoning campaign pledged to keep future oil drilling out and "racial restrictions in perpetuity." Additionally, an "informed local opinion" assured appraisers "that this factor [oil wells] is not a deterrent" (A58 HOLC 1939). Even in El Segundo, a company town founded by Standard Oil, where "oil wells, refinery and tank farms" were all "derogatory influences," and the beach was "defiled by a large outfall sewer and oil tanker docks and loading facilities," redlining was ruled out because residents protected their properties against "racial hazards." El Segundo received a "high yellow" grade and was even lauded as a "model for neatness and upkeep" (C108 HOLC 1939). Based on the variability of oil in appraisers' reports, it is clear that when appraisers described oil production as a significant factor in their appraisal, a neighborhood only gained negative value when paired with threats to white homogeneity. The discussions among residents, agents, and assessors considered oil production negotiable in property appraisals, and final decisions pivoted on the larger threat posed by racially "subversive" Angelenos. 
The oil industry's infrastructure of drilling, refining, and transporting posed contradictory meanings in different social spaces. The industry remained benign as long as African Americans and Latinos were locked in place through racially restrictive covenants. Yet once "racial subversion" slipped past vigilant white residents, appraisers marked the neighborhood and its petro-chemical industries "hazardous." White suburbanites who maintained white supremacy through the rule of contract could therefore control the influence of noxious industries through the same paper technologies, rejecting real estate hazards while actual toxic effluence seeped into their neighborhood's air, land, and water. ${ }^{2}$

The majority of oil towns and petro-suburbs, however, lacked the legal infrastructure to protect the whiteness of their community. Indeed, it cost money to organize neighbors and file racially restrictive covenants with local courthouses. Many of the working-class neighborhoods, in turn, suffered redlining grades that imperiled the future of homeowners' investments. ${ }^{26}$ As oil workers and their families moved out, a phenomenon known as "white flight," African Americans and Latinos arriving in Los Angeles found some of their only housing options in the redlined communities. Residents once limited to the historically black neighborhoods of South Central and Watts, in particular, moved farther south and east across the Basin into Hawthorne, Gardena, Compton, Carson, Torrance, Wilmington, Inglewood, and Long Beach. By the 1970s, South Los Angeles's white working class had been largely supplanted by its black and brown counterparts, with many living in redlined neighborhoods proximate to oil production.

In 1937, the FHA commissioned an additional map of the region. The map plotted the region's subterranean oil fields and pinpointed oil wells along with corporate boundaries. The stark contrast between surface-level political interests, etched in angular, territorial formations, and underground oil deposits, globular and with no allegiance to surface politics, spread across the basin. In rendering visible a non-human environment once geologically concealed, the FHA also rendered invisible the in-between, a human-built environment characterized by commercial buildings, houses, streets, and train lines (FHA 1937).

The map's very existence is surprising, considering the FHA's work subsidizing home mortgages. Without knowing exactly how the map was used in mortgage lending, one can infer its purpose by layering it with the residential security map. The oil deposits and redlined properties align. To federal appraisers, the basin's substrata were important factors in creating housing market value. Contemporary oil operations, with their industrial features sketched in detail, were given ecological weight by processes millions of years in the making, while future housing markets were shaped by the predictability of soon-to-be oil operations. Unlike any other metropolis appraised by the FHA, Los Angeles's underground helped underwrite an above ground regime of racialized investment and divestment.

\footnotetext{
${ }_{25}$ Oil work, as an occupation, also appeared as a factor that affected an area's overall grade. In many, if not most, of the red- and yellow-lined oil properties, "oil men" were listed as residents. This typology rested inconsistently next to other more generalizable descriptions of occupations. The oil industry may also have undermined property values through the placement of its employees.

${ }_{26}$ For a study of suburban redlining in Flint, MI, see Highsmith (2015).
} 


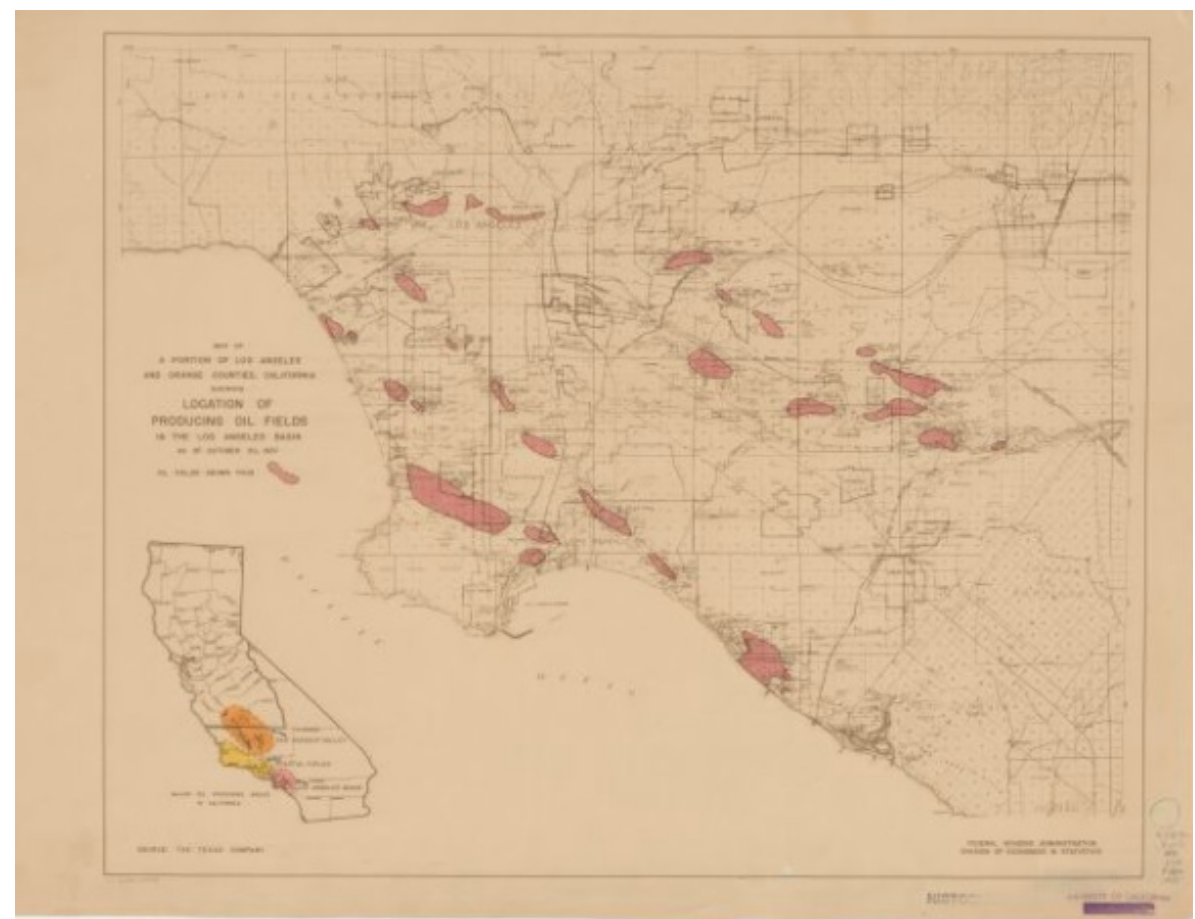

Figure 5. "Location of Producing Oil Fields" (Federal Housing Administration 1937).

The engineering of subsurface resources and topsoil politics in both HOLC and FHA maps reveals the environmental politics of segregationist lending policy from the 1930s until the Fair Housing Act of 1968. Under public pressure in 1947, the FHA removed from its manual all direct references to race. A year later the Supreme Court ruled that racial covenants could not be legally enforced. In reality, the court ruling only outlawed formal mechanisms of racial lending. Entrenched institutional practices, and the redlining maps themselves, continued to inform lending decisions for decades. Furthermore, redlining's consequences to human health would remain far more difficult to erase, especially as oil companies continued to operate in a segregated landscape that became increasingly populated.

\section{“Any Exposure at All Is Dangers" Post-WWII}

In the 1940s, the Los Angeles Sentinel, a leader in the region's black press, charged the FHA with creating "ghettos for American Negroes." The Sentinel implicated the federal government in financing a segregated housing market that lacked "health protection" and failed to provide a "good environment" (Editorial 1938). Real estate developers had constructed environmental inequality through heavy industries and restrictive lending, the effects of which now rendered redlined communities toxic to its residents. Unlike their white neighbors, however, moving away 
from blight was not an option for most working-class African Americans. In the postwar era, only a small number of black residents were able to move to the periphery's leafy suburbs, such as Pacoima (Weise 2004).

Currently, West Adams, a historic neighborhood for middle-class African Americans, features active drill sites; and Baldwin Hills, known as the "Black Beverly Hills," sits next to the 1,000-acre Inglewood Oil Field. Willowbrook, an unincorporated African American community between Watts and Compton, maintains an active oil refinery with dozens of oil wells buried under its industrial lots. Farther south, Carson, an incorporated city, and Wilmington, a Los Angeles neighborhood, both home to significant percentages of low and middle-income black and Latino residents, host most of the county's petro-chemical refineries and have hundreds of oil wells spread throughout their residential districts. There are now 5,194 active oil wells in Los Angeles County. 1 in 3 people lives within one mile of a well, and the majority are residents of color (Natural Resources Defense Council 2014; Liberty Hill Foundation 2015).

A recent court-ordered release of toxic substances litigation reveals the petroleum industry's long-held knowledge about the dangers of oil production, highlighting its role in perpetuating a toxic relationship between industry and resident health. In 1943, an internal report for Shell Oil labeled "CONFIDENTIAL" warned of dangerous chemicals, declaring "any exposure at all is dangerous" (Soley 1943). The American Petroleum Institute conducted a 1948 investigation that concluded benzene, among other carcinogenic chemicals, could be related to high rates of cancer among employees (API 1948). A 1950 internal memo to an executive at Shell Oil listed, in two-and-a-half pages, "Certain Problems of Environmental Cancer in the Petroleum Industry." (Hine 1950). Revealing the industry's priorities as late as 1977, litigation attorneys for Shell Oil standardized their "Duties, Defenses, and Strategies" for fighting cases of "Benzene Litigation" (Faulk 1977). Corporate suppression of knowledge in the postwar era, and the industry's mobilizations in legal self-defense, fit seamlessly with its historical priorities of profit over people. Combined with decades of redlining, oil production fixed in place a toxic environment for generations of black and brown communities forced to live in the backyard of the fossil fuel industry.

\section{Conclusion}

The distinctive geology of the Los Angeles Basin continues to shape political contests over environmental justice today. In the 1980s, Latina women in East Los Angles and black women in South Central launched an environmental justice movement that fought against neighborhood exploitation, including the expansion of oil pipelines and placement of toxic incinerators (Bullard 1994). Activists a generation later are fighting a familiar battle, this time over hydraulic fracturing and acidization in Los Angeles's oil fields. Industry advocates support the new technology's capability to re-stimulate old fields, and more importantly, do so under safety regulations that are among the best in the nation. Residents who live near the operations, however, claim the revamped industry causes nosebleeds, headaches, cancer, and even premature death (STANDLA 2013). Historical scholarship attentive to the legal, infrastructural, and political technologies 
utilized to engineer the uneven burdens of resource extraction has much to offer these evolving debates.

Indeed, histories of the underground, as this article shows, are crucial for pushing dialogue beyond limited discourses of proximity, regulation, and the burden of proof when communities claim harm. Dismantling the technologies that underwrite such harm, however, requires more than decoding racist mapping. It begins with recognizing that white supremacy's commitment to extraction runs deep. Globally, oil-rich countries such as Nigeria and Venezuela are characterized by the "resource curse," which can easily misattribute the corrupting influence of wealth to an inherent quality of the resource itself, instead of parsing how the exploitation of people and resources is produced through the spectacular and mundane practices of governance. In Los Angeles, where extractive exploitation begins with the underground, it is crucial that scholars examine underlying conditions that reproduce racial inequality above ground, particularly in spaces such as suburbia, where assumptions of social mobility can easily hide its contradictions.

The instant that speculators struck oil in 1892, notions of what, or more importantly who, threatened property accumulation were rearticulated through an ecotechnological system that remade both nature and society. Relying on fallacious ideas relating race to property value, real estate developers constructed a segregated housing market, and federal redlining reserved the benefits of oil production for a white middle class, while depositing its burdens on communities of color. By redlining oil properties only under threat of racial subversion, federal appraisers ensured that neighborhoods with weak property regulations would be exposed to industrial hazards. As petroleum fueled Los Angeles's massive sprawl, the industry's externalities, toxins such as benzene, toluene, xylene, and formaldehyde, among others, seeped into land, water, and air, silently poisoning black and Latino residents long after white residents fled to greener pastures. Indeed, many of the early inhabitants of the region's petro-suburbs, such as Olinda, moved to leafier suburbs, far removed from their blue-collar origins. For the black and Latino Angelenos who moved in, however, lingering effects of the petro-industry remained in their lungs, bones, and blood, compounding the economic inequalities of redlining with an environmental toxicity waged daily against their bodies.

As this article demonstrates, redlining was not only a process of allocating resources across horizontal territory, it was also a process deeply related to the mapping of the underground, a crucial technique in underwriting urban apartheid. Urban historians have yet to integrate this third dimension into their analysis, while scholars of technology are only beginning to examine the instruments that helped vertically engineer a housing market in the interests of white wealth and health. This article, in turn, reveals the interlocking technologies that produced oil as a natural resource and inequality as a persistent feature of the modern metropolis.

After holding onto her Signal Hill property for nearly a decade, Mary Craig Sinclair sold her two lots in 1930. She earned a few thousand dollars. Like the rest of the neighborhood, federal appraisers redlined her lots under the compounding threat of industrial and racial subversion (D63 HOLC 1939). It appears it was Sinclair's good fortune to buy property before the oil boom, and she sold her holdings at just the right moment. The entire affair may even seem 
serendipitous. However, Sinclair's luck might be better understood as a manifestation of the "racial contract," a political commitment to reproducing white supremacy lying at the heart of liberal society (Mills 1997). Contract relations that, for example, provided white Angelenos with access to the "right" properties at the "right" times. At the core of Los Angeles's petro-modernity, the racial contract reaffirmed residents' commitment to white supremacy through restrictive property rights, hazardous industries, exclusive neighborhoods, and segregationist policies.

Upton Sinclair certainly understood the extractive nature of industrial capitalism. After he and Mary sold their property, he launched a third campaign for governor in 1934. Running on the Democratic ticket instead of the Socialist Party, his typical affiliation, Sinclair's anti-poverty platform won him the nomination. While Sinclair didn't win the general election, his campaign manifesto, "End Poverty In California," suggests he might have recognized the racial contract underwriting, and appraising, property values atop the Los Angeles oil fields (Sinclair 1934). He should have, anyway; Oil! earned him a new home in Beverly Hills, and with Mary, Upton Sinclair left Signal Hill behind.

\section{Acknowledgements}

I would like to thank the scholars who contributed to this STS Underground thematic collection and the editors at ESTS. Special thanks to Robyn d'Avignon for her consistent support and insightful critiques throughout the entire process. Additional thanks to Andrew Needham for providing thoughtful feedback on drafts of this article. I would also like to thank my colleagues at New York University who offered constructive commentary on earlier iterations of the article, including fellow graduate students in seminar and the NYU Urban Intellectual History Workshop.

\section{Author Biography}

Daniel Cumming is a Ph.D. candidate in the History Department at New York University. He studies twentieth-century US urban history, in particular the intersections of racism, capitalism, and built and natural environments.

\section{References}

A. Hoen \& Co., and R. Arnold. 1906. Street and section map of the Los Angeles oil fields, California. Baltimore: A. Hoen \& Co. Map. Retrieved from the Library of Congress. Accessed 23 January 2018. https: / / www.loc.gov/item/2006627664/.

American Petroleum Institute. 1948. "API Toxicological Review, Benzene, September 1948." In Toxic Docs: Version 1.0, edited by M. Chowkwanyun, J.A. Farrill, G. Markowitz, and D. Rosner. New York: Columbia University and City University of New York. Accessed 2 February 2018. http://www.toxicdocs.org. 
Appel, Hannah. 2012. “Offshore Work: Oil, Modularity, and the How of Capitalism in Equatorial Guinea." American Ethnologist 39(4): 692-709.

Avila, E. 2004. Popular Culture in the Age of White Flight: Fear and Fantasy in Suburban Los Angeles. Berkeley: University of California Press.

Bakker, K., and G. Bridge. 2006. "Material Worlds? Resource Geographies and the 'Matter of Nature'." Progress in Human Geography 30(1): 5-27.

Beal, C.H. 1930. Appraisal of the Oil Properties of the Richfield Oil Company and Subsidiary Companies as of December 31, 1929. Los Angeles: Beal-Heller-Corby.

Beko, K. 1979. Pipelines to the Past: An Oral History of Olinda, California. The Oral History Program: California State University, Fullerton.

Bowling, Harry. 1920. “This Land of Infinite Variety." Los Angeles Times, January 1, 1920, VI3.

Braun, B. 2000. "Producing Vertical Territory: Geology and Governmentality in Late Victorian Canada." Cultural Geographies 7(7): 7-46.

Bridge, G. 2009. "Material Worlds: Natural Resources, Resource Geography and the Material Economy." Geography Compass 3(3): 1217-1244. . 2013. “Territory, now in 3D!” Political Geography 34: 55-57.

Bullard, R.D. 1994. Unequal Protection: Environmental Justice and Communities of Color. San Francisco: Sierra Club Books.

Californians, Inc. 1923. “California, build Your Tomorrow Here.” Sunset 50: 84.

California State Data Center. "Historical Census Populations of Counties and Incorporated Cities in California, 1850-2010," Demographic Research Unit, Department of Finance, State of California. $\quad$ Accessed $23 \quad$ January 2018. http:/ / www.dof.ca.gov/Reports/Demographic_Reports/.

Cowgill, D.O., and M.S. Cowgill. 1951. "An Index of Segregation Based on Block Statistics." Americal Sociological Review 16(6): 825-831.

Cronon, W. 1991. Nature's Metropolis: Chicago and the Great West. New York: W.W. Norton \& Company.

Davis, M. 1997. "Sunshine and the Open Shop: Ford and Darwin in 1920s Los Angeles." Antipode 29(4): 356-382.

Deverell, W. 2005. Whitewashed Adobe: The Rise of Los Angeles and the Remaking of Its Mexican Past. Berkeley: University of California Press.

Drake, S.C., and H.R. Cayton. 1945. Black Metropolis: A Study of Negro Life in a Northern City. Chicago: University of Chicago Press.

Editorial. 1938. "Ghettoes, American Style." Los Angeles Sentinel, December, 29, 1938, 1.

Elkind, S. S. 2011. How Local Politics Shape Federal Policy: Business, Power, and the Environment in Twentieth-Century Los Angeles. Chapel Hill: The University of North Carolina Press.

Ervin, J.M. 1931. "The Participation of the Negro in the Community Life of Los Angeles." MA thesis, University of Southern California.

Ethington, P.J., W.H. Frey, and D. Myers. 2001. “The Racial Resegregation of Los Angeles County, 1940-2000." Race Contours 2000 Study, Public Research Report no. 2001-04. 
Faulk, R.O. 1977. "Benzene Litigation: Duties, Defenses and Strategies." In Toxic Docs: Version 1.0, edited by M. Chowkwanyun, J.A. Farrill, G. Markowitz, and D. Rosner. New York: Columbia University and City University of New York. Accessed 2 February 2018. http:// www.toxicdocs.org.

Federal Housing Administration. 1936. Underwriting Manual: Underwriting and Valuation Procedure Under Title II of the National Housing Act. Washington, DC: U.S. Government Printing Offices.

1937. Map of a portion of Los Angeles and Orange Counties, California, showing location of producing oil fields in the Los Angeles Basin as of October 20, 1937. Washington: Federal Housing Administration, Division of Economics \& Statistics. Accessed 23 January 2018. http: / / digital2.library.ucla.edu / viewItem.do?ark=21198/ zz002c1bm7.

Ferry, E. and M.E. Limbert. 2008. "Introduction." In Timely Assets: The Politics of Resources and Their Temporalities, edited by E. Ferry and M.E. Limbert, 3-24. Santa Fe: School for Advanced Research Press.

Flamming, D. 2006. Bound for Freedom: Black Los Angeles in Jim Crow America. Berkeley: University of California Press.

Freund, D.M.P. 2007. Colored Property: State Policy and White Racial Politics in Suburban America. Chicago: University of Chicago Press.

Gardner, Bradford. "Our Gay Black Way: Central Avenue." Los Angeles Times, June 18, 1933, H4.

Gotham, K.F. 2002. Race, Real Estate, and Uneven Development: The Kansas City Experience, 19002010. Albany: State University of New York Press.

Greer, J. 2013. "The Home Owners' Loan Corporation and the Development of the Residential Security Maps." Journal of Urban History 39(2): 275-296.

Gregory, J.N. 2006. The Southern Diaspora: How the Great Migrations of Black and White Southerners Transformed America. Chapel Hill: The University of North Carolina Press.

Gutierrez, D.G. 1995. Walls and Mirrors: Mexican Americans, Mexican Immigrants, and the Politics of Ethnicity. Berkeley and Los Angeles: University of California Press.

Highsmith, A.R. 2015. Demolition Means Progress: Flint, Michigan, and the Fate of the American Metropolis. Chicago: University of Chicago Press.

Hillier, A.E. 2005. “Residential Security Maps and Neighborhood Appraisals: The Home Owners' Loan Corporation and the Case of Philadelphia." Social Science History 29(2): 207-233.

Hine, C.H. 1950. "Certain Problems of Environmental Cancer in the Petroleum Industry." In Toxic Docs: Version 1.0, edited by M. Chowkwanyun, J.A. Farrill, G. Markowitz, and D. Rosner. New York: Columbia University and City University of New York. Accessed 2 February 2018. http:/ / www.toxicdocs.org.

Hirsch, A.R. 2000. "Containment on the Home Front: Race and Federal Housing Policy from the New Deal to the Cold War." Journal of Urban History 26(2): 158-189.

Hise, G. 2001. "Nature's Workshop: Industry and Urban Expansion in Southern California, 19001950." Journal of Historical Geography 27(2): 74-92.

Hughes, T.P. 2004. Human-Built World: How to Think About Technology and Culture. Chicago: University of Chicago Press. 
Jackson, K.T. 1985. Crabgrass Frontier: The Suburbanization of the United States. Oxford: Oxford University Press.

Klingle, M. 2007. Emerald City: An Environmental History of Seattle. New Haven: Yale University Press.

Kruse, K.M., and T.J. Sugrue. 2006. The New Suburban History. Chicago: University of Chicago Press.

Kurashige, S. 2008. The Shifting Grounds of Race: Black and Japanese Americans in the Making of Multiethnic Los Angeles. Princeton: Princeton University Press.

Lerman, N.E. 2010. "Categories of Difference, Categories of Power: Bringing Gender and Race to the History of Technology." Technology and Culture 51(4): 893-918.

Liberty Hill Foundation. 2015. "Drilling Down: The Community Consequences of Expanded Oil Development in Los Angeles." Accessed 23 January 2018. https:// www.libertyhill.org/sites/libertyhillfoundation/files/Drilling\%20Down\%20Re port $\% 20-\% 20$ Full.pdf.

Lipsitz, G. 1998. The Possessive Investment in Whiteness: How White People Profit from Identity Politics. Philadelphia: Temple University Press.

Loewen, J. 2005. Sundown Towns: A Hidden Dimension of American Racism. New York: Touchstone.

Los Angeles Times. 1930. “When Wilshire Struck Oil.” January 13, 1930, 15. . 1930. “New Questions Will Be Asked." April 20, 1930, D4. . 1930. "World's Agricultural 'White Spot' Here." November 16, 1930, A1. . 1930. "Production Totals Reveal Los Angeles County as Bonanza Land." November 17, 1930, A2.

. 1932. “Tell Truth or Stop Selling' Decree Issued.” November 13, 1932, 17.

Marciano, R., D. Goldberg, and C. Hou. "T-RACES: A Testbed for the Redlining Archives of California's Exclusionary Spaces." Accessed 23 January 2018. http://salt.umd.edu/TRACES.

Marx, L. 2010. "Technology: The Emergence of a Hazardous Concept." Technology and Culture 51(3): 561-577.

Massey, D.S., and N.A. Denton. 1993. American Apartheid: Segregation and the Making of the Underclass. Cambridge, Mass: Harvard University Press.

Mills, C.W. 1997. The Racial Contract. New York: Cornell University Press.

Natural Resources Defense Council. 2014. “Drilling in California: Who's At Risk?" Accessed 23 January 2018. https://www.nrdc.org/sites/default/files/california-fracking-risksreport.pdf.

Needham, A. 2014. Power Lines: Phoenix and the Making of the Modern Southwest. Princeton: Princeton University Press.

Nelson, R.K., L. Winling, R. Marciano, and N.D.B Connolly. 2016. "Mapping Inequality," in American Panorama, edited by R.K. Nelson and E.L. Ayers. Accessed 23 January 2018. https: / / dsl.richmond.edu/panorama/redlining/\#loc $=11 / 33.8402 / 118.2496 \&$ opacity $=0.8$ \&sort $=308,316,318 \&$ text $=$ about $\&$ city $=$ los-angeles-ca. 
Nicolaides, B. 2002. My Blue Heaven: Life and Politics in the Working-Class Suburbs of Los Angeles, 1920-1965. Chicago: University of Chicago Press.

Nixon, R. 2011. Slow Violence and the Environmentalism of the Poor. Cambridge, Mass.: Harvard University Press.

Pulido, L. 2000. "Rethinking Environmental Racism: White Privilege and Urban Development in Southern California." Annals of the Association of American Geographers 90(1): 12-40.

Quam-Wickham, N. 2001. "'Another World': Work, Home, and Autonomy in Blue-Collar Suburbs." In Metropolis in the Making: Los Angeles in the 1920s, edited by T. Sitton and W. Deverell. 166-202. Berkeley: University of California Press.

Richardson, T. and G. Weszkalnys. 2014. "Resource Materialities." Anthropological Quarterly 87(1): 5-30.

Robinson, C. 1983. Black Marxism: The Making of the Black Radical Tradition. London: Zed Press.

Rolston, J.S. 2013. "The Politics of Pits and the Materiality of Mine Labor: Making Natural Resources in the American West." American Anthropologist 115(4): 582-594.

Sabin, P. 2005. Crude Politics: The California Oil Market, 1900-1940. Berkeley: University of California Press.

Sanchez, G.J. 1993. Becoming Mexican American: Ethnicity, Culture and Identity in Chicano Los Angeles, 1900-1945. New York: Oxford University Press.

Schmitt, R.J., J.E. Dugan, and M.R. Adamson. 2003. Industrial Activity and Its Socioeconomic Impacts: Oil and Three Coastal California Counties. Coastal Research Center, Marine Science Institute, University of California, Santa Barbara.

Sinclair, U. 1934. I, Governor of California and How I Ended Poverty, A True Story of the Future. Los Angeles: End Poverty League.

Soley, M.H. 1943. "Report to Shell Development Company on Benzenes, Nitrobenzenes, Anilines and Xylidines (Their Toxic Effects and Suggested Safeguards in Manufacturing Processes), September 7, 1943." In Toxic Docs: Version 1.0, edited by M. Chowkwanyun, J.A. Farrill, G. Markowitz, and D. Rosner. New York: Columbia University and City University of New York. Accessed 2 February 2018. http: / / www.toxicdocs.org.

STAND—L.A. 2013. “STAND—LA." Accessed 23 January 2018. http:/ / www.stand.la/.

Sugrue, T. 1996. Origins of the Urban Crisis: Race and Inequality in Postwar Detroit. Princeton: Princeton University Press.

Tygiel, J. 1997. "Forward." In Oil! A Novel, by U. Sinclair. Berkeley: University of California Press.

U.S. Energy Information Administration. "U.S. Crude Oil First Purchase Price." Petroleum and Other Liquids, U.S. Department of Energy. Accessed 23 January 2018. https: / / www.eia.gov/dnav/pet/hist/LeafHandler.ashx?n=pet\&s=f000000_3\&f=a.

Viehe, F. W. 1981. "Black Gold Suburbs: The Influence of the Extractive Industry on the Suburbanization of Los Angeles, 1890-1930." Journal of Urban History 8(1): 3-26.

Weszkalnys, G. 2014. "Anticipating Oil: The Temporal Politics of a Disaster Yet to Come." The Sociological Review 62(1): 211-35.

. 2015. "Geology, Potentiality, Speculation: On the Indeterminacy of First Oil." Cultural Anthropology 30(4): 611-39. 
Whittemore, A.H. 2012. “Zoning Los Angeles: A Brief History of Four Regimes." Planning Perspectives 27(3): 393-415.

Wiese, A. 2004. Places of Their Own: African American Suburbanization in the Twentieth Century. Chicago: University of Chicago Press.

Wilson, P.N. 1923. "All Within the Law: How Oil Sharks Trim Their Victims and Still Keep Out of Jail." Sunset 50: 32-33, 56.

Woehlke, W. 1910. "California's Black Gold: The Romance of the Oil Gushers." Sunset 2: 173-187

Workers of the Writers' Program of the Work Project Administration in Southern California. 1941. Los Angeles: A Guide to the City and Its Environs. Los Angeles County Board of Supervisors, American Guide Series. New York: Hastings House.

Yerkes, R.F., T.H. McCulloh, J.E. Schoellhamer, and J.G. Vedder. 1965. Geology of the Los Angeles Basin California - An Introduction. Washington: U.S. Government Printing Office.

Youle, W.E. 1926. Sixty-three Years in the Oilfields. Fuller Printing Company. 